\title{
Implementation of the Use of Lecture Method in Filing Subjects at the Department of Office Vocational School YPLP PGRI 1 Makassar
}

\author{
Muslimin ${ }^{1}$, Sirajuddin Saleh$^{2}$, Muh. Darwis ${ }^{3}$ \\ 1,2,3 Universitas Negeri Makassar \\ E-mail: imin.muslimin@gmail.com
}

\begin{abstract}
In an effort to educate the life of the nation, then one way that can be done is through education. This research aims to determine the implementation of the lecture method use in archival subjects in the Department of Office Vocational School YPLP PGRI 1 Makassar. This research uses qualitative research with a qualitative descriptive approach. Informants in this study were 5 (five) people. Data collection was carried out through interviews, observation and documentation techniques. The data that has been collected is processed using analytical techniques namely data reduction, data presentation and conclusions or verification. The results showed that the use of lecture methods in archival subjects in the Department of Office SMK YPLP PGRI 1 Makassar, in general, has been well implemented. This is assessed from the three stages in the use of the lecture method, the first is the preparation phase carried out by the teacher before starting the implementation of learning in the classroom which results are categorized as good, the second stage of the implementation starts from the opening step and the presentation step by the teacher when the class is assessed to be running well, and the third step ends/closes the lecture where the results are also considered to be going well. So the use of lecture methods in archival subjects at the Department of Office Vocational School YPLP PGRI 1 Makassar has been implemented well
\end{abstract}

Keywords: Implementation, methods, learning, lectures

\section{INTRODUCTION}

In an effort to educate the life of the nation, one way that can be done is through education (Akib \& Saleh, 2015; Suprianto, Arhas, \& Salam, 2018; Syarifuddin, 2016). Education is a major factor in the formation of good or bad human person (Sirait, Arhas, \& Suprianto, 2019). Aware of this, the government is very serious in handling the education sector, because with a good education system, it is expected that the next generation of qualified and capable of adapting themselves to live in a society, nation, and state

The renewal of education is applied in various ways. As educators, teachers must know and be able to implement educational reform in order to develop a conducive learning process so that maximum results can be obtained. One form of renewal learning by utilizing learning methods that are active, effective and fun for students in interesting ways so that students' curiosity about the subject matter increases (Arhas, 2018). It's no longer the time for a teacher to only rely on lectures in delivering material. Teachers are required to be active and creative in guiding students toward learning goals.

Copyright (C) 2019 Universitas Negeri Makassar. This is an open access article under the CC BY license (http://creativecommons.org/licenses/by/4.0/) 


\author{
96 Jurnal Administrare: Jurnal Pemikiran Ilmiah dan Pendidikan Administrasi Perkantoran \\ Volume 6 Number 2 July- December 2019. Pages 95-104
}

The main task of a teacher is to educate, teach and train students (Fransiska, 2016; Salam, Zunaira, \& Niswaty, 2016). To be able to carry out these tasks properly, teachers must be able to master a variety of abilities. One of the abilities that must be mastered is to develop themselves professionally. This means, teachers are not only required to master teaching material or be able to present it appropriately but are also required to be able to assess their own performance. This ability is related to research which is mainly focused on the circumstances surrounding the classroom, namely research in the classroom itself.

Determining the method or technique of learning activities is an important step that can support the success of achieving goals. The activity must be adjusted to the goal. In determining this learning activity the teacher must determine which activities are necessary and unnecessary. There are many choices for a teacher in carrying out learning. One way is to use the lecture method. One of the most commonly used learning methods is the lecture learning method. It is different from other learning methods, for example the project method, the experimental method, the discussion method, the demonstration method, and others. The lecture learning method is the most traditional or classical learning method that has long been used in education (Afandi, Chamalah, \& Wardani, 2013; Maimunah, 2016; Olusegun, 2015; Sani, 2014). Although the lecture learning method in the history of education is a classical method, the method is still relevant for use even the majority of educators in the world of educational content still use lecture learning methods in collaboration with other learning methods. Therefore, to be able to know the extent of success that can be achieved by students in mastering the subjects given by the teacher in the classroom, then the lecture learning method is used as one of the learning strategies.

\title{
METHOD
}

This research is a type of research that uses qualitative research as a research procedure that produces a description of written and oral words from people and observable behavior, which is carried out at SMK YPLP PGRI 1 Makassar. The data source in this study consisted of 5 informants namely the head of the office administration department, 1 subject teacher and 3 students. The focus of this research will describe the implementation of the use of lecture methods in archival subjects with indicators of the preparation stage, the implementation stage and the closing stage of learning. Data collection techniques used are observation, interviews, and documentation. Checking the validity of the data used is the extension of observation, triangulation and member checks. While the data analysis techniques used are data condensation, data presentation, and conclusions.

\section{RESULT AND DISCUSSION}

The results of research conducted at SMK YPLP PGRI 1 Makassar against 5 informants, using the interview method as the most important data collection tool, in order to obtain data about the implementation of the use of lecture method in archival subjects in the Department of Office of SMK YPLP PGRI 1 Makassar. Informants in this study are Rahmawati, S.Pd, Ulfa Magvirah, S.Pd., Rizal, Wahyuni and Tri Ardianti. To find out the implementation of the lecture method use in archival subjects in the Department of Office Vocational School YPLP PGRI 1 
Makassar can be seen through the responses of informants who are considered representative and observations obtained in the field. For more details, will be described in detail based on interviews obtained from each indicator:

\section{Preparation Phase}

In the preparation phase, the teacher prepares conditions for students to learn by doing apperception. After checking the attendance list, the teacher communicates to students in the form of questions about students' readiness to take lessons that day. With enthusiasm, by using the Indonesian language the teacher tries to involve students both physically and psychologically to prepare themselves to follow the lesson. This communication is used to foster student interest in the lessons and material that will be delivered. That way students become more excited and ready to follow the learning.

The first step in the preparation phase is the formulation of learning objectives. Formulation of learning objectives after conditioning students to be ready to learn, then the teacher conveys learning objectives or competency standards and basic competencies to be achieved at each meeting. Then the teacher explains how the learning objectives can be achieved. What is conveyed by the teacher is in accordance with the learning objectives that have been made in the learning implementation plan or often abbreviated as RPP. Each semester the teacher must make initial plans that are formulated in the syllabus and lesson plans that will be used when learning in class, because it is an obligation for a teacher to prepare everything starting from the learning objectives made in the syllabus and other learning materials. In learning, there are no significant obstacles because sometimes they can be overcome easily. Because the difficulty depends on the material to be delivered and the ability of students, and usually the difficulty is found. In formulating learning it is quite easy and surely students will easily reach the learning goals. But in reality the learning objectives are very difficult to achieve by students. The teacher does not know whether at that time students are really not interested in the material they have given, but sometimes the material that is considered difficult for students actually easily achieves the learning objectives. Besides that, the observations made by researchers regarding the teacher preparation stage in formulating learning objectives, which generally seen all teachers always prepare learning materials at the beginning of the semester by making various learning materials ranging from syllabus, lesson plans, and learning tools to be used to teach in class.

The second step in the preparation session is the subject matter which after the teacher explains the learning objectives then the teacher then starts the subject matter. The teacher directly submits archival material presented with explanatory material explanations. A teacher determines the subject matter to be discussed, while the benchmark is to look at textbooks because the book used is in accordance with the existing syllabus. So the compilation of learning objectives is in accordance with the syllabus, the teacher only needs to continue the previous learning. When the teacher explains the material about archiving, the teacher does not experience problems, because the teacher always discusses the material to be discussed at the next meeting, so that students have the opportunity to find and use previously the material to be discussed by the teacher. However, teachers who have difficulty in choosing material to be used for grade II students. Sometimes teachers also have difficulty determining the sources or library materials to be used, which are appropriate for students or not, so students' abilities are 


\author{
98 Jurnal Administrare: Jurnal Pemikiran Ilmiah dan Pendidikan Administrasi Perkantoran \\ Volume 6 Number 2 July- December 2019. Pages 95-104
}

different. So students who are quick to answer explanations or questions from the teacher, then they will also quickly speak what are the indicators while students who do not understand or quickly understand will come out from other friends. Based on responses from interviews and also the results of research conducted by researchers regarding the preparation of learning materials, which can refute discussions about the teacher that can be done to make good preparation for learning, and also the teacher has been able to determine the subject matter that has been provided with a variety of literature contained in the syllabus, and besides determining the subject matter also based on seeing the condition or character of students in receiving the explanation of the subject matter.

\title{
Implementation Stage
}

The implementation phase is the procession stage of learning in the classroom, in this implementation phase a teacher must prepare the opening step and the step of the presentation. The way to open learning is done as a kearispan teacher by giving a freelance story to students, and for new students, an introduction is made to be more intimate with students and in addition, it must be done for the opening in teaching by the teacher by explaining the objectives learning materials. Regarding the opening done by the teacher it is known that there are several ways that are often done in opening learning, some are telling stories freely with students about life and there are also by explaining the learning objectives to be taught at that time. However, in opening learning not all teachers do attendance at the beginning of learning, sometimes there are also teachers who simply explain the subject matter and later at the end of the material then the teacher does attendance.

Based on the results of the interview above, it is known that in this implementation phase, especially in the opening step aspect, the teacher generally performs the opening phase by giving appreciation and absentee activities, so it can be concluded that the opening step carried out by the teacher has been implemented well. In the learning process the teacher has tried to teach by paying attention to students' gestures when the teacher explains the subject matter, and the teacher also always seeks to explain the subject matter in simple language and accompanied by concrete examples that can be directly observed by students. The explanation above can be concluded that the implementation of the lecture method at the implementation stage, in general, can be said to have been going well, this can be seen by the process of opening and presentation steps carried out by archival subject teachers who have all been carried out systematically.

\section{Closing Stage of Learning}

The final process before being approved is finally guiding/asking students to make or make conclusions on the lessons that have been submitted and after students provide comments related to the subject matter then the teacher conducts an evaluation. From this evaluation the teacher can find out the level of achievement of the learning objectives that have been formulated. in general the teacher compilation has explained all the subject matter and before ending the learning in class, then a teacher usually asks one of the students to give a conclusion on the material that has been agreed by the teacher. As a teacher is usually also done before holding a meeting in class is to discuss a little material that will be discussed at the next meeting, discussing that students can do first at home before the material is discussed in class. 
Evaluation by the teacher at the end of the lesson is important for the teacher to do so that the teacher can understand about students' level of understanding in receiving subject matter. The evaluation process is often done by teachers in general by giving assignments, be it the task of making summaries or assignments by giving questions that will be done by each student in Animal Husbandry. There are also teachers who support meetings that can be done also by providing motivation to students, the motivation provided is the motivation to learn that is needed so students can be more motivated to study hard, and what is done is done to prove that teachers must be able to help these students have approved subject matter delivered.

Based on some of the information above it can be concluded that the implementation of learning to end or close the lecture can be said to have gone well, where this can be said so because the teacher conducts a question and answer system to students on the material that has been delivered then the teacher or student tries to give the conclusion of all the material that has been taught on that day, and after that the teacher also asks students to work on assignments whose purpose is to evaluate the extent of the success of learning done by the archiving teacher.

Of the three aspects above related to the use of lecture methods in archival subjects through the three aspects of the lecture method namely aspects of the preparation stage, the opening stage and the steps to end/close the lecture in which all three aspects are said to have gone well, this means it can be assessed the use of the method lectures on archival subjects by teachers at the Vocational School YPLP PGRI 1 Makassar, in general, can be said to have been implemented well.

\section{Discussion}

\section{Preparation Phase}

Regarding the preparation phase by the teacher in determining the subject matter, which can be concluded that in general, the teacher has been able to prepare well for learning. The preparation phase carried out by the archiving teacher is in the form of preparing syllabus and lesson plans and preparing learning materials and preparing learning tools to be used when teaching and learning in class.

The preparation phase undertaken by the teacher especially the archival subject teacher is considered to have gone up, this is because the teacher formulates the learning objectives to be achieved related to the competency of archival subjects in the formulation of these objectives formulated in the syllabus and lesson plan of the archival subjects. In the process of formulating goals carried out by archiving teachers in SMK YPLP PGRI 1 Makassar sometimes find obstacles to formulating goals such as sometimes teachers find it difficult to chronicle the subject matter contained in the literature with the current field conditions used.

Based on these learning objectives a teacher can develop various ways through materials, methods, and media to achieve the goals that have been formulated by conducting an assessment or evaluation to ensure that the expected goals are actually achieved. This goal covers the skills that must be mastered by students to be implemented. According to (Sanjaya, 2015) this goal is an operational objective that students can achieve in a short amount of time when study hours are over.

$\mathrm{n}$ the process of teaching and learning that learning objectives in the form of instructional goals are a very important factor, with the establishment of clear objectives the direction of 
100 Jurnal Administrare: Jurnal Pemikiran Ilmiah dan Pendidikan Administrasi Perkantoran

Volume 6 Number 2 July- December 2019. Pages 95-104

learning in accordance with educational goals. According to Sadiman in (Sanjaya, 2015), learning objectives are statements that indicate the behavior that must be achieved by students after following a certain instructional process. Formulating learning objectives in the form of instructional goals must be oriented towards students with stated operational verbs. These instructional objectives have two types, namely general instructional objectives and specific instructional objectives. General instructional objectives are the ultimate goal of instructional activity. Whereas specific instructional objectives are intermediary objectives to achieve general instructional goals.

After finding the learning objectives outlined in the lesson plan, the teacher then determines the main points of the material which is the way the teacher uses to condition the class regarding the time of using the lecture method. After knowing the subject matter that must be delivered to students, the teacher will not use this lecture method which can help learning to become very monotonous and busy. The use of the lecture method needs to be accompanied by the use of assistive devices. This is done to improve the quality of lectures conducted. Allows students to understand the subject matter properly and can achieve the learning goals that have been previously formulated.

Apart from the teacher's duty to determine the learning objectives, the teacher as well as the teacher should master the material or subject matter that will be taught and always develop and improve their abilities. Because it is actually the teacher himself is a student who is learning continuously. Teachers are a place to gain knowledge for their students. As a teacher, he must help the development of his students to understand, and master knowledge. For this reason the teacher should be able to motivate students to always learn on various occasions. This ability is not only based on theories obtained from education but must be lived and addressed as an art. As we know elementary school teachers not only have to master one subject area of study, but rather all subjects. Therefore continuous learning to explore teaching materials is inevitable.

The teacher is said to be someone who manages the learning activities for the students. Everything related to learning activities in the classroom becomes the authority and responsibility of the teacher. Any learning resources that will be used in the classroom are entirely in the hands of the teacher. Learning methods which will be applied in the classroom to present certain subject matter are also the responsibility of the teacher. Even though there is already a guide about the learning methods that are set for the teacher to use in presenting the subject matter, but still the teacher has the authority to choose and determine the learning methods that will be used in the classroom.

The main task of the teacher is to teach students, namely to condition students to learn actively so that their potential (cognitive, affective, and psychomotor) can develop optimally. With active learning, participation in each learning activity, will be trained and competence is formed which is the ability of students to do something positive in the end which will shape life skills as a provision of life and livelihood. So that the above can be realized, the teacher should know how students learn and master various ways of learning students. Teaching and learning activities are connected with the way the teacher delivers the subject matter so that it can be understood by students receiving the material delivered by the teacher. So that student learning activities are much influenced by teacher activities. In teaching and learning activities, learning media is something that can be used as a means of connecting to achieve the message that must be achieved by students in learning activities. Often we find other terms that are similar or may have the same connotation, namely "teaching aids" and "learning aids", of the three 
understanding experts behave by distinguishing them, but those who use them with the same interpretation.

\section{Implementation Stage}

At the implementation stage for the lecture method conducted by the teacher in the learning process in the classroom, there are two steps of concern for the teacher namely the opening step and the presentation step. From the results of the study found by researchers, which is known that the implementation of the lecture method at the implementation stage, in general, can be said to have been going well, this is because in the opening step by the teacher by giving an explanation to the students in advance about the purpose of the material he will be invited, after that at this stage the teacher will also conduct an appreciation activity in which the teacher will review some of the previous subject matter by linking the material that will be delivered at the ongoing meeting.

The implementation phase activities carried out by the archival teacher at SMK YPLP PGRI 1 Makassar are also a learning tradition that exists at SMK YPLP PGRI 1 Makassar, where the majority of teachers at SMK YPLP PGRI 1 Makassar generally conduct appreciation activities at the beginning of the learning process in class. It is very important for a teacher to carry out creative activities before the subject matter is delivered to students, where the goal is to measure or assess students' understanding of the material that has been taught at the previous meeting. Whereas at the implementation stage in the presentation step undertaken by the YPLP PGRI 1 Makassar Vocational School teacher, this was also considered to be good, because in the process of delivering subject matter to students, archival teachers always tried to keep eye contact with students, and aside from that, The teacher also tries to provide an explanation of the material using easy language so that students can more easily digest each word or sentence delivered by the teacher.

The learning objectives will be well realized, if the teacher can explain the subject matter well too, therefore, a teacher must be able to explain or explain the subject matter systematically and be able to respond to all questions or responses from students about the material presented. The YPLP PGRI 1 Makassar Vocational School teacher, especially the archival subject teacher, has shown the teaching process using the lecture method by always explaining the subject matter systematically, which means that the archival teacher is trying to explain each of the main points of discussion and also the teacher always responds to the students' questions by answering the students' questions.

\section{Closing Stage of Learning}

A teacher who uses the lecture method in the learning process must be closed so that learning materials that are understood and mastered by students do not fly anywhere. Create activities that allow students to keep remembering the subject matter. From the results of research on the steps to end or close the lecture which is considered to have gone well, where this can be said so because the teacher can perform various activities in the process of closing learning in class, such as first, guiding students to draw conclusions or summarize the subject matter just delivered by the teacher. Second, stimulate students to be able to make a response or 


\section{Jurnal Administrare: Jurnal Pemikiran Ilmiah dan Pendidikan Administrasi Perkantoran Volume 6 Number 2 July- December 2019. Pages 95-104}

give some kind of review about the learning material that has been delivered. Third, the teacher evaluates to find out how far his students master the learning material that he just submitted.

Regarding this end-stage is also very important for a teacher, because in the ways that are done as described above, a teacher can judge by knowing the extent to which students understand the subject matter that has been described. In addition, at the end of the class meeting a teacher is also diligent in giving homework to students whose purpose is to train students' level of understanding of the material taught to them. For the subject matter of the filing, it indeed seems to indeed seem to require a lecture method as an explanatory and developer step-by-step of making and practicing a kearsipan system. However, the use of this method does not exceed beyond the allotted time, because it will take up the time of students to pay attention in the classroom and outside the classroom. For this reason, archival participants must be able to manage the class and see the situation of students. Then the teacher should be able to explain the steps of work in detail because usually, students are more difficult to carry out a good archive of storage according to the type or archive system used.

The problem of the method of delivering archival subject matter used by the teacher during the learning process can be by not using the lecture method, but by utilizing the media so that the teacher saves more time to explain and students will more quickly understand the material without having to feel bored listening to the teacher's explanation. As stated by (Uno, 2010) that the lecture method is a way of presenting lessons through verbal closure or direct explanation to a group of students. The use of good and appropriate lecture methods will make it easier for teachers to deliver subject matter and students will be younger at understanding teacher explanations. In order for this lecture method to succeed, there are a number of things that the teacher must pay attention to, both at the preparation stage and at the implementation stage.

According to (Sanjaya, 2008) that the teacher plays an important role in the teaching and learning process. Teaching and learning process as a system of activities carried out in the classroom or outside the classroom. The teacher selects and ranks the learning material, the application and use of learning methods, the delivery of learning material, the instructor of learning, to the evaluation of learning outcomes.

Every teacher who teaches must find a problem, especially if you have to teach students who are already known to be all different from each student, there are those who have a good level of understanding and some who are lacking. Problems found in the teaching and learning process are based on the components in the learning process. As stated by (Sanjaya, 2010) components in the learning process, namely objectives, subject matter, learning methods or strategies, media, and evaluation. Before conducting learning a teacher is obliged to make a teaching device that originates from the syllabus also called the design of the learning process. This teaching tool is a weapon for teachers to make students learn. Of course, before this device is used the teacher must first arrange carefully. But the main part that must be made by the teacher is to formulate in advance the learning objectives to be carried out.

\section{CONCLUSION}

Based on the results of research and discussions that have been carried out by researchers, it can be understood that the use of lecture methods in archival subjects in the office department of SMK YPLP PGRI 1 Makassar has generally been well implemented. This is assessed from 
the three stages in the use of the lecture method, which is the teacher's preparatory stage before starting the implementation of learning in class. The results are categorized as good, both stages of implementation start from the opening step and the presentation step by the teacher when in class are considered to be going well, and which the three steps to end/close the lecture where the results are also considered to be going well.

\section{REFERENCES}

Afandi, M., Chamalah, E., \& Wardani, O. P. (2013). Model Dan Metode Pembelajaran Di Sekolah. In Perpustakaan Nasional Katalog Dalam Terbitan (KDT). https://doi.org/10.1007/s00423-006-0143-4

Akib, H., \& Saleh, S. (2015). Pengaruh Kepala Sekolah Sebagai Supervisor Terhadap Kinerja Guru Di Smk Negeri 7 Makassar. Jurnal Office, 1(2), 141-147.

Arhas, S. H. (2018). Metode Pembelajaran Black Knight. Apa? Mengapa? dan Bagaimana? Jurnal Ad'ministrare, 5(2), 165-172.

Fransiska, C. (2016). Pengaruh Kompetensi Profesional Guru Terhadap Kualitas Proses Pembelajaran Pada Paket Keahlian Administrasi Perkantoran Di Smk Negeri 1 Bungoro Kabupaten Pangkep. Jurnal Office, 2(2), 163-172.

Maimunah, M. (2016). Metode Penggunaan Media Pembelajaran. Al-Afkar: Jurnal Keislaman \& Peradaban. https://doi.org/10.28944/afkar.v5i1.107

Niswaty, R., \& Arhas, S. H. (2019). The Effect of Learning Media on Progress Quality in Office Administration Program in Vocational School Negeri 1 Watampone Bone Regency. Journal of Physics: Conference Series, 1387. https://doi.org/10.1088/1742-6596/1387/1/012042

Olusegun, S. (2015). Constructivism Learning Theory: A Paradigm for Teaching and Learning. IOSR Journal of Research \& Method in Education Ver. I. https://doi.org/10.9790/7388-05616670

Salam, R., Zunaira, Z., \& Niswaty, R. (2016). Meningkatkan Hasil Belajar Membuat Dokumen melalui Penggunaan Model Pembelajaran Kooperatif Tipe Make a Match (Mencari Pasangan). Jurnal Office, 2(2), 173-180.

Sani, R. A. (2014). Pembelajaran Saintifik Untuk Implementasi Kurikulum 2013. Bumi Aksara.

Sanjaya, W. (2008). Kurikulum Dan Pembelajaran (Teori \& Praktek KTSP).

Sanjaya, W. (2010). Strategi Pembelajaran Berorientasi Standar Proses Pendidikan. System.

Sanjaya, W. (2015). Perencanaan dan Desain Sistem Pembelajaran. Kencana,Prenadamedia Group. 
104 Jurnal Administrare: Jurnal Pemikiran Ilmiah dan Pendidikan Administrasi Perkantoran Volume 6 Number 2 July- December 2019. Pages 95-104

Sirait, E. J. M., Arhas, S. H., \& Suprianto, S. (2019). The Influence of Assignment of Lecturers at School (ALS) Program on Students Learning Motivation in Tarakan City. Jurnal Ad'ministrare, 6(1), 79-88.

Sukmawati, S. (2017). Implementasi Pendidikan Karakter di Sekolah Menengah Pertama Negeri Kabupaten Maros. Jurnal Ad'ministrare: Jurnal Pemikiran Ilmiah dan Pendidikan Administrasi Perkantoran, 4(2), 76-82.

Suprianto, S., Arhas, S. H., \& Salam, R. (2018). Pengaruh Media Pembelajaran dan Pengelolaan Kelas terhadap Prestasi Belajar Siswa di SMK Negeri Kecamatan Tanete Riattang, Kabupaten Bone. Jurnal Ad'ministrare, 5(2), 137-146.

Syarifuddin, S. (2016). Peningkatan Hasil Belajar Materi Kepadatan Penduduk Melalui Alat Peraga "Plate Area" Dengan Model Pembelajaran Snowball Throwing. Jurnal Office, 2(2), 97-102.

Uno, H. H. B. (2010). Model pembelajaran: menciptakan proses belajar mengajar yang kreatif dan efektif. In Jakarta: Bumi Aksara. https://doi.org/10.1038/cddis.2011.1 